\title{
Sistem Informasi Berbasis Web Pada Kearsipan Surat Di Universitas Muhammadiyah Sumatera Barat
}

\author{
Hariyadi $^{1,2}$, Ambiyar ${ }^{3}$, Nurhasan Syah $^{4}$ \\ Mahasiswa S3 PTK UNP ${ }^{1}$, Dosen Universitas Muhammadiyah Sumatera Barat ${ }^{2}$, Dosen \\ Universitas Negeri Padang ${ }^{3,4}$ \\ Email: hariefamili@yahoo.co.id ${ }^{1,2}$, ambiyar@ft.unp.ac.id ${ }^{3}$,nurhasan12@gmail.com ${ }^{4}$ \\ DOI: http://dx.doi.org/10.31869/rtj.v5i1.2975
}

\begin{abstract}
Abstrak: Arsip merupakan salah satu sumber informasi penting yang dapat menunjang proses kegiatan administrasi maupun birokrasi. Sebagai rekaman informasi dari seluruh aktivitas organisasi, arsip berfungsi sebagai pusat ingatan, alat bantu pengambilan keputusan, bukti eksistensi organisasi dan untuk kepentingan organisasi yang lain. Berdasarkan fungsi arsip yang sangat penting tersebut maka harus ada manajemen atau pengelolaan arsip yang baik sejak penciptaan sampai dengan penyusutan, sebelum diterapkannya mempunyai kelemahan-kelemahan, di antaranya sebagai berikut: Terjadi kesulitan dalam mencari atau mendapatkan akses kembali data arsip yang akan dibutuhkan karena harus mencari satu persatu pada buku induk, Terjadinya kehilanngan surat masuk, Proses disposisi surat Masuk yang lama, dikarenakan Pimpinan ada kegiatan yang harus dipenuhi, Surat masih disimpan dalam rak almari arsip sehingga dari tahun ketahun surat semakin banyak dan almari arsip tidak mampu menampung arisip, namun setelah diterapkan arsip surat berbasiskan website didapat manfaat sebagai berikut: Kehilangan Surat Masuk/Keluar yang dahuluya sering terjadi, setelah diterapkan SIKD berbasis website, surat sudah dapat dikendalikan dan disimpan dimedia penyimpanan online, Proses disposisi surat Masuk yang sangat cepat dikarenakan dapat diakses kapanpun dan dimanapun sehingga selama ini pimpinan yang biasa ada tugas atau dinas keluar, sudah dapat didisposisi dari manapun, Surat sudah disimpaan pada media online yang tidak butuh lemari arsip/ruangan khusus lagi
\end{abstract}

Kata Kunci: Arsip, SIDK, Online, Website, Sistem Informasi

\section{PENDAHULUAN}

Era globalisasi ditandai dengan perkembangan teknologi dan informasi yang semakin maju, berimbas pada meningkatnya kebutuhan manusia akan informasi. Informasi merupakan hal yang sangat penting dalam berbagai kegiatan yang dilakukan oleh manusia. Berbagai macam dokumen dan media telah tercipta untuk kemudahan manusia dalam menyimpan, mencari dan menyebarkan informasi. Dokumen- dokumen tersebut lebih dikenal sebagai arsip, yang berarti suatu rekamam kegiatan atau peristiwa yang telah terjadi ${ }^{1}$

Arsip, merupakan salah satu sumber informasi penting yang dapat menunjang proses kegiatan administrasi maupun birokrasi. Sebagai rekaman informasi dari seluruh aktivitas organisasi, arsip berfungsi sebagai pusat ingatan, alat bantu pengambilan keputusan, bukti eksistensi organisasi dan untuk kepentingan organisasi yang lain. Berdasarkan fungsi arsip yang sangat penting tersebut maka harus ada manajemen atau pengelolaan arsip yang baik sejak penciptaan sampai dengan penyusutan ${ }^{2}$
Masalah kearsipan belum sepenuhnya menjadi perhatian baik oleh masyarakat umum, organisasi pemerintah maupun organisasi swasta. Banyak orang yang masih belum memahami arti penting dan manfaat arsip dalam kehidupan sehari-hari, dalam pelaksanaannya masih banyak ditemui arsiparsip yang menumpuk di dalam lemari tidak tersusun rapi sehingga sulit untuk ditemukan kembali apabila dibutuhkan untuk keperluan tertentu. Akibat dari hal ini tentunya informasi yang terkandung di dalam arsip tidak terjamin keamanannya.

Arsip dapat bermanfaat bagi suatu organisasi apabila dikelola dengan tertib dan teratur, namun sebaliknya apabila arsip dikelola dengan tidak tertib akan menimbulkan masalah bagi suatu organisasi. Apabila suatu arsip sulit untuk ditemukan maka akan menjadi hambatan dalam proses pengambilan keputusan dan akan mempersulit proses hukum dan pertanggungjawaban. Surat yang ditangani oleh organisasi salah satunya adalah penanganan surat masuk dan surat keluar. Mengingat dengan pentingnya surat dalam suatu organisasi, karena organisasi tanpa surat 
dapat dikatakan sebagai organisasi yang kurang efektif. Agar kegiatan persuratan dapat berjalan dengan baik, maka perlu adanya pengelolaan surat yang tertib dan lancar. Hal ini dimaksudkan agar dalam melaksanakan kegiatan persuratan dapat terhindar dari berbagai macam permasalahan permasalahan yang dapat terjadi dalam bidang persuratan. $^{3}$

Pemberkasan arsip aktif menghasilkan tertatanya informasi dan fisik arsip. Begitu pentingnya arsip bagi kemaslahatan seluruh bangsa Indonesia, negara melalui UndangUndang Nomor 43 Tahun 2009 tentang Kearsipan khususnya Pasal 9 ayat (3) telah mengamanatkan kepada seluruh pencipta arsip untuk melaksanakan pengelolaan arsip dinamis, yang meliputi arsip vital, arsip terjaga, arsip aktif, dan arsip inaktif. Setiap organisasi wajib melakukan pemberkasan arsip agar dapat membantu kelancaran aktivitas suatu organisasi ${ }^{4}$.

Oleh sebab itu pemanfaatan teknologi informasi dan komunikasi dalam berupa media komputer juga menjadi alasan mengapa arsip harus dikelola secara elektronik. Dengan adanya media elektronik seperti komputer dan aplikasi-aplikasi berbasiswa desktop maupun web dapat membantu proses pengelolaan dan pengurusan arsip akan menjadi lebih mudah dan tidak akan memakan waktu lama. Pemanfaatan komputer dapat menjadikan arsip konvensional menjadi digital atau juga dapat menciptakan arsip elektronik. Penggunaan media elektronik dalam pengelolaan arsip inilah yang sering disebut sebagai Sistem Pengarsipan Elektronik (Electronic Filing System) yang berbasiskan pada penggunaan komputer..

\section{METODE}

Metodologi penelitian merupakan suatu proses yang digunakan untuk memecahkan suatu masalah yang logis menggambarkan apa adanya dengan teknik pengumpulan data langsung dari sumbernya, membaca dan mempelajari sumber-sumber berupa buku, literature, serta mewawancarai staf yang bekerja di Agendaris Universitas Muhammadiyah Sumatera Barat

\section{HASIL DAN PEMBAHASAN}

Berdasarkan UU No. 43 Tahun 2009, pengertian arsip yaitu: "Rekaman kegiatan atau peristiwa dalam berbagai bentuk dan media sesuai dengan perkembangan teknologi informasi dan komunikasi yang dibuat dan diterima oleh lembaga negara, pemerintahan daerah, lembaga pendidikan, perusahaan, organisasi politik, organisasi kemasyarakatan, dan perorangan dalam pelaksanaan kehidupan bermasyarakat dan bernegara".

SIKD adalah sistem pengolahan arsip berbasis teknologi informasi yang dirancang untuk menangani pengelolaan arsip dinamis, dikembangkan oleh Arsip Nasional Republik Indonesia (ANRI) Universitas Muhammadiyah Sumatera Barat Mendapatkan Hibah Prgram tersebut pada tahun 2019. Aplikasi ini adalah web based application dan bersifat multi user. Bahasa pemrograman yang dipergunakan dalam aplikasi ini adalah PHP dan menggunakan database MYSQL.

Arsip di Universitas Muhammadiyah Sumatera Barat sebelum diterapkannya system informasi kearsipkan berbasiskan website, mempunyai kelemahan-kelemahan, di antaranya sebagai berikut:

a. Terjadi kesulitan dalam mencari atau mendapatkan akses kembali data arsip yang akan dibutuhkan karena harus mencari satu persatu pada buku induk.

b. Terjadinya kehilanngan surat masuk

c. Proses disposisi surat Masuk yang lama, dikarenakan Pimpinan ada kegiatan yang harus dipenuhi

d. Surat masih disimpan dalam rak almari arsip sehingga dari tahun ketahun surat semakin banyak dan almari arsip tidak mampu menampung arisip

Menurut Siatiras (dalam Sugiarto 2014: 87) penerapan manajemen elektronik memiliki beberapa manfaat yaitu:

1. Peningkatan efisiensi dalam pelayanan terhadap klien internal dan eksternal,

2. Peningkatan berbagi informasi antara staf dan kantor,

3. Mengurangi kewajiban atau manajemen resiko,

4. Peningkatan keamanan informasi,

5. Peningkatan pencatatan dan administrasi informasi,

6. Keamanan yang fleksibel di tingkat dokumen, bukan hanya di level direktori versi control,

7. Peningkatan proses informasi dan auditability,

8. Tidak ada duplikasi dokumen, 
9. Peningkatan akses ke informasi.

Persepsi tentang Pengelolaan Arsip setelah menggunakan Sistem Informsai Kearsipan Dinamis (SIKD) di Universitas Muhammadiyah Sumatera Barat, dari hasil wawancara bersama Pihak Rektorat Universitas Muhammadiyah Sumatera Barat

1. Sistem Pengelolaan Kearsipan

Agendaris mengatakan tidak ada masalah dengan sistem yang digunakan, apapun sistemnya yang penting sesuai dengan kaidah kearsipan yang berlaku. Pimpinan di tingkat pusat dan fakultas mengatakan bahwa pengelolaan arsip di Universitas Muhamammadiyah Sumatera Barat sudah mulai dikelola dengan baik. Hal tersebut dibuktikan dengan dibentuknya Bagian Umum / Agendaris dimasing-Masing Unit Fakultas sehingga Semua Surat yang Masuk terdata dan didisposisi Melalui Sistem

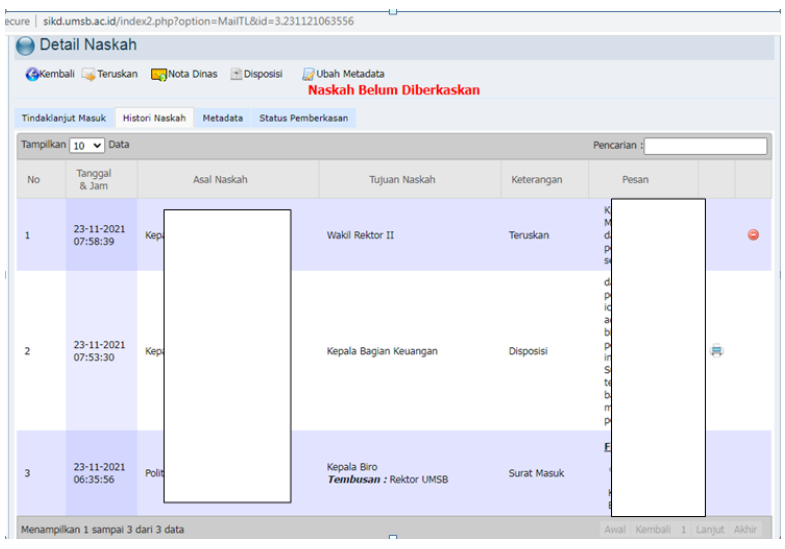

Gambar 1. Tampilan Hasil Disposisi

2. Sumber Daya Manusia

Saat ini di Universitas Muhammadiyah Sumatera Barat terdapat 12 orang arsiparis yang berada dibawah Bagian Umum, sehingga pemerataan di masingmasing fakultas sudah merata.

3. Sarana Prasarana Kearsipan SIKD

Dalam hal prasarana kearsipan (gedung), sebagian Univesitas dan Fakultas belum menyediakan ruangan Khusus secara maksimal, namun terkait karena berupa Software pihak Universitas menyediakan Sebuah Komputer Server yang terhubung dengan Internet $24 \mathrm{Jam}$, sehingga Sistem Informasi SIKD dapat diakses kapanpun dan dimanapun oleh Pemangku Kepentingan yang terlibat dalam Prosos Surat Menyurat terutama Disposisi Surat melalui website www.sikd.umsb.ac.id

4. Penyajian Arsip

Dalam penyajian arsip disajikan dalam waktu yang cepat karena sudah terintegrasi dengan Sistem Informasi berbasiskan website

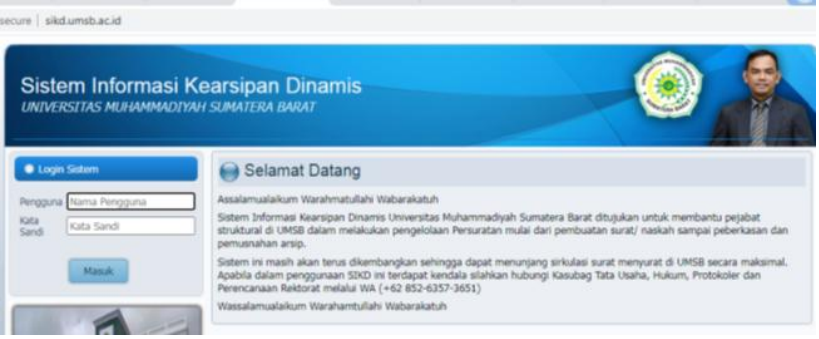

Gambar 2. Tampilan Utama Website SIKD

Setelah diterapkannya pengelolahan Arsip berbasiskan website melalui www.sikd.umsb.ac.id dalam kaitannya dengan pengambilan keputusan, diperoleh hasil sebagai berikut :

a. Dalam hal pencarian Arsip, Sudah mudah dikarenakan tidak perlu lagi mencari pada lemari arsip. Agendaris cukup mencari pada tombol pencarian, sehingga mudah dalam mencari rekam jejak surat yang telah masuk atau didisposisi

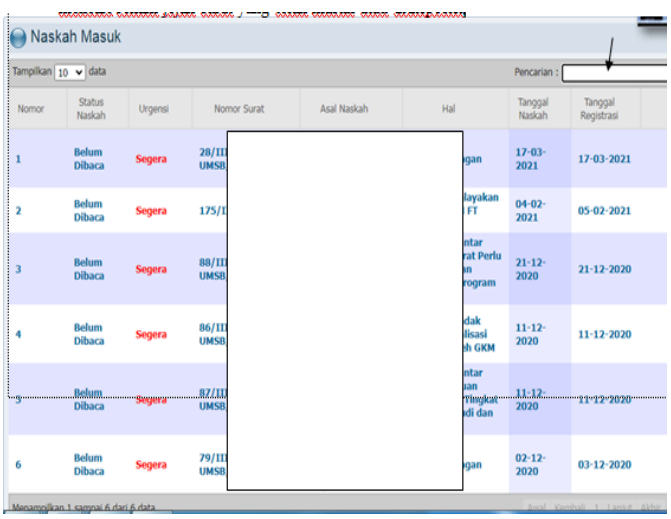

Gambar 3. Tampilan Proses Pencarian Arsip

b. Kehilangan Surat Masuk/Keluar yang dahuluya sering terjadi, setelah diterapkan SIKD berbasis website, surat sudah dapat dikendalikan dan disimpan dimedia penyimpanan online

c. Proses disposisi surat Masuk yang sangat cepat dikarenakan dapat diakses kapanpun dan dimanapun sehingga selama ini pimpinan yang 
biasa ada tugas atau dinas keluar, sudah dapat didisposisi dari manapun.

d. Surat sudah disimpaan pada media online yang tidak butuh lemari arsip/ruangan khusus lagi

\section{PENUTUP}

Sistem Informasi Kearsipan Dinamis (SIKD) medapatkan beberapa Manfaaat di Universitas Muhammadiyah Sumatera Barat Sistem Pengelolaan Kearsipan dikelolah secara Online, sehingga tidak membutuhkan ruangan Khusus, yang dibutuhkan adalah Agendaris dan Pihak yang berkepentingan/ terlibat harus paham dengan penggunaan SIKD berbasiskan website. Namun perlu disarankan kepada bagian Teknologi Informasi untuk dapat mengamankan sistem agar ditidak diganggu oleh pihak yang tidak berkepentingan.

\section{DAFTAR PUSTAKA}

1. Rifauddin, Machsun. "Pengelolaan arsip elektronik berbasis teknologi." Khizanah al-Hikmah: Jurnal Ilmu Perpustakaan, Informasi, dan Kearsipan 4.2 (2016): 168-178.

2. Fathurrahman, Muslih. "Pentingnya arsip sebagai sumber informasi." JIPI (Jurnal Ilmu Perpustakaan Dan Informasi) 3.2 (2018): 215-225.

3. Hendriyani, Mungky. "Pengendalian Surat Masuk Menggunakan Aplikasi Sistem Informasi Kearsipan Dinamis (SIKD) di Subbagian Persuratan dan Arsip Aktif Pada Arsip Nasional Republik Indonesia." KOMPLEKSITAS: JURNAL ILMIAH MANAJEMEN DAN ORGANISASI 9.2 (2020): 37-46.

4. Hendriyani, Mungky. "PEMBERKASAN ARSIP DINAMIS AKTIF DI SUBBAGIAN PERSURATAN DAN ARSIP AKTIF PADA ARSIP NASIONAL REPUBLIK INDONESIA (ANRI)." KOMPLEKSITAS: JURNAL ILMIAH MANAJEMEN DAN ORGANISASI 10.01 (2021): 11-17.

5. Adawiyah, Rabiatul, and Elva Rahmah. "Penerapan Aplikasi Arsip Sistem Informasi Kearsipan Dinamis (SIKD) dalam Melakukan Alih Media Arsip Nagari di Kantor Wali Nagari Pitalah Kecamatan Batipuh Kabupaten Tanah
Datar." Ilmu Informasi Perpustakaan dan Kearsipan 7.1 (2018): 132-142

6. Undang-Undang Republik Indonesia Nomor 43 Tahun 2009. Kearsipan. Jakarta. 